\title{
Genetic correlation estimates between beef fatty acid profile with meat and carcass traits in Nellore cattle finished in feedlot
}

\author{
Fabieli Loise Braga Feitosa ${ }^{1}$ - Bianca Ferreira Olivieri ${ }^{1}$ - Carolyn Aboujaoude ${ }^{1}$. \\ Angélica Simone Cravo Pereira ${ }^{2} \cdot$ Marcos Vinicius Antunes de Lemos ${ }^{1}$. \\ Hermenegildo Lucas Justino Chiaia ${ }^{1}$. Mariana Piatto Berton ${ }^{1} \cdot$ Elisa Peripolli $^{1}$. \\ Adrielle Matias Ferrinho ${ }^{2}$ - Lenise Freitas Mueller $^{3}$ - Mônica Roberta Mazalli ${ }^{4}$. \\ Lucia Galvão de Albuquerque ${ }^{1,5}$ - Henrique Nunes de Oliveira ${ }^{1,5}$ - Humberto Tonhati ${ }^{1,5}$. \\ Rafael Espigolan $^{1}$ - Rafael Lara Tonussi ${ }^{1}$ - Rafael Medeiros de Oliveira Silva ${ }^{1}$. \\ Daniel Gustavo Mansan Gordo ${ }^{1}$ - Ana Fabrícia Braga Magalhães ${ }^{1}$ Ignacio Aguilar ${ }^{6}$. \\ Fernando Baldi ${ }^{1,5}$
}

Received: 15 December 2015 /Revised: 10 March 2016 / Accepted: 5 July 2016 / Published online: 30 July 2016

(C) Institute of Plant Genetics, Polish Academy of Sciences, Poznan 2016

\begin{abstract}
The objective of this study was to estimate the genetic-quantitative relationships between the beef fatty acid profile with the carcass and meat traits of Nellore cattle. A total of 1826 bulls finished in feedlot conditions and slaughtered at 24 months of age on average were used. The following carcass and meat traits were analysed: subcutaneous fat thickness (BF), shear force (SF) and total intramuscular fat (IMF). The fatty acid (FA) profile of the Longissimus thoracis samples was determined. Twenty-five FAs (18 individuals and seven groups of FAs) were selected due to their importance for human health. The animals were genotyped with the BovineHD BeadChip
\end{abstract}

Communicated by: Maciej Szydlowski

Fabieli Loise Braga Feitosa bifeitosa@hotmail.com

1 Department of Animal Science, Faculty of Agrarian and Veterinarian Sciences, Sao Paulo State University, Jaboticabal, SP, Brazil

2 Department of Animal Science, School of Veterinary Medicine and Animal Science, University of Sao Paulo, Pirassununga, SP, Brazil

3 Department of Animal Science, Faculty of Animal Science and Food Engineering, University of Sao Paulo, Pirassununga, SP, Brazil

4 Department of Food Engineering, Faculty of Animal Science and Food Engineering, University of Sao Paulo, Pirassununga, SP, Brazil

5 National Counsel of Technological and Scientific Development, CNPq, Brasília, DF, Brazil

6 National Agricultural Research Institute, INIA, Las Brujas 90200, Uruguay and, after quality control for single nucleotide polymorphisms (SNPs), only 470,007 SNPs from 1556 samples remained. The model included the random genetic additive direct effect, the fixed effect of the contemporary group and the animal's slaughter age as a covariable. The (co)variances and genetic parameters were estimated using the REML method, considering an animal model (single-step GBLUP). A total of 25 multi-trait analyses, with four traits, were performed considering SF, BF and IMF plus each individual FA. The heritability estimates for individual saturated fatty acids (SFA) varied from 0.06 to 0.65 , for monounsaturated fatty acids (MUFA) it varied from 0.02 to 0.14 and for polyunsaturated fatty acids (PUFA) it ranged from 0.05 to 0.68 . The heritability estimates for Omega 3, Omega 6, SFA, MUFA and PUFA sum were low to moderate, varying from 0.09 to 0.20 . The carcass and meat traits, $\mathrm{SF}(0.06)$ and $\operatorname{IMF}(0.07)$, had low heritability estimates, while BF $(0.17)$ was moderate. The genetic correlation estimates between SFA sum, MUFA sum and PUFA sum with BF were 0.04, 0.64 and -0.41 , respectively. The genetic correlation estimates between SFA sum, MUFA sum and PUFA sum with SF were 0.29, -0.06 and -0.04 , respectively. The genetic correlation estimates between SFA sum, MUFA sum and PUFA sum with IMF were $0.24,0.90$ and -0.67 , respectively. The selection to improve meat tenderness in Nellore cattle should not change the fatty acid composition in beef, so it is possible to improve this attribute without affecting the nutritional beef quality in zebu breeds. However, selection for increased deposition of subcutaneous fat thickness and especially the percentage of intramuscular fat should lead to changes in the fat composition, highlighting a genetic antagonism between meat nutritional value and acceptability by the consumer. 
Keywords Bosindicus · Fat · Meattenderness · Meatquality · Human health · Selection

\section{Introduction}

The zebu breeds have some advantages, such as better adaptation to tropical environment and resistance to parasites (Cundiff 2004). However, compared to taurine breeds or crossbreds, zebu breeds produce carcasses with lower fat content, harder meat and lower percentage of intramuscular fat. Meat quality is associated with organoleptic characteristics such as colour, flavour, tenderness and juiciness, and these attributes are influenced by factors such as finishing, fat deposition and marbling of the meat. Thus, the meat produced from zebu breeds in tropical and sub-tropical regions has organoleptic characteristics that, in general, are not well accepted by more demanding markets.

Currently, there is a continuing and growing concern about excessive fat consumption, especially animal fat, and the fat composition of the meat. The ruminant fat is a natural source of conjugated isomers of linoleic acid (CLA), such as c9t11 (French et al. 2000), and has other essential polyunsaturated fatty acids (PUFA), such as linoleic and linolenic, and monounsaturated fatty acids (MUFA), such as oleic acid, which are beneficial to human health (Becker et al. 1983; Ip 1997; Pensel 1998; Simopoulos 2008). However, meat also has saturated fatty acids (SFA), which, in general, are associated with the increase of low-density lipoproteins (LDL). This is due to the effect of acids such as lauric and myristic, which reduce the activity of LDL receptors in the liver, increasing LDL concentration in plasma (Givens 2005).

Although meat from Bos indicus cattle is, generally, less tender and has lower percentage of intramuscular fat compared to Bos taurus, Rossato et al. (2010) reported that meat from Nellore is nutritionally healthier compared to Angus meat. Huerta-Leidenz et al. $(1993,1996)$ and Perry et al. (1998) compared the composition of adipose tissue of Bos taurus and Bos indicus, and reported that zebu meat has a lower content of SFA than taurine breeds. Therefore, if zebu meat is moderately consumed, it should not cause problems to human health, as it has desirable characteristics, such as low fat content, typically from 2-4\% of intramuscular fat, and a fatty acid profile with high levels of the omega 3 (n-3) fatty acid series (Prado et al. 2003). Although several studies have reported differences in the fatty acid profile among breeds (Mills et al. 1992; Huerta-Leidenz et al. 1993, 1996; Siebert et al. 1996; Malau-Aduli et al. 1997; Rule et al. 1997; MalauAduli et al. 1998; Pitchford et al. 2002), these differences may be mistaken by differences in fat deposition or precocity between breeds (De Smet et al. 2004). According to these authors, breeds with higher fat deposition or greater finishing precocity have a smaller PUFA/SFA ratio and have, therefore, less healthy meat.

Despite its relevance in tropical regions, genetic improvement programmes for carcass and meat traits in zebu cattle have been limited in cattle. Several studies have emphasised the need to improve the meat quality of zebu animals, by increasing tenderness, carcass fat thickness or intramuscular fat. However, there is still little information on the impact of selection for these traits on the composition of fat, particularly intramuscular fat. De Smet et al. (2004) stated that the fatty acid composition influences greatly the juiciness, flavour and tenderness of the meat. Therefore, the knowledge of the phenotypic and genetic correlations between carcass and meat traits with the fatty acid profile of the meat is necessary. There are few studies, most with taurine breeds, which have quantified the genetic associations between the beef fatty acid profile with carcass and meat traits. In this context, Nogi et al. (2011) and Kelly et al. (2013) studied the genetic-quantitative relationships between the fatty acids profile with carcass and meat traits and concluded that changes in fat composition are expected when selection is applied to the carcass and meat traits.

In order to improve the meat quality of Bos indicus raised in the tropics, information on genetic parameters for carcass and meat traits, fatty acid composition and genetic-quantitative relationships between these traits is essential to improve meat tenderness and the proportion of fat in the carcass, without harming the fat composition in zebu breeds. Therefore, this study aimed at estimating the genetic-quantitative relationships between carcass and meat traits and the fatty acid profile of Nellore.

\section{Materials and methods}

\section{Animals and information management}

This study was approved by the ethics committee of the Faculty of Agrarian and Veterinarian Science, Sao Paulo State University (UNESP).

A total of 1826 Nellore bulls finished in feedlot for a minimum period of 90 days and slaughtered at 24 months of age on average were used. The animals belonged to eight different farms located in the southeast, northeast and midwest regions of Brazil, which participate in three beef cattle breeding programmes (Nelore Qualitas, Paint and DeltaGen). In these breeding programmes, animals are selected based on growth, finishing and sexual precocity traits. The owners of these farms have agreed to carry out this study and gave their permission to conduct the study. The field studies did not involve endangered or protected species.

Different breeding season periods are adopted on these farms; therefore, calving seasons concentrate from August to 
October in some farms and from November to January in others. The calves were weaned at approximately 7 months old. The animals were raised grazing on Brachiaria sp. and Panicum sp. forages, with free access to mineral salt. After yearling, the breeding animals were selected and the rest remained in feedlots for a period of at least 90 days. During feedlot, the forage:concentrate ratio ranged from 50:50 to 70:30, depending on the farm. In general, whole-plant corn or sorghum silage was used as high-quality forage. Grains of corn and/or sorghum, and soybeans, soybean meal or sunflower seeds were used as protein concentrate.

\section{Carcass and meat traits}

The slaughters were carried out in commercial slaughterhouses, in accordance with the Brazilian Federal Inspection Service procedures. After storage for $48 \mathrm{~h}$ in a cold room at 0 $2{ }^{\circ} \mathrm{C}, 2.5$-cm-thick samples were collected from the Longissimus thoracis, between the 12th and 13th ribs of each left half carcass for the analyses described below.

\section{Back fat thickness (BF)}

A vernier caliper was used to measure the subcutaneous fat layer, placed at a $45^{\circ}$ angle from the geometric centre of the sample. The thickness of the body fat layer is expressed in millimetres.

\section{Shear force (SF)}

The procedure proposed by Wheeler et al. (1995) was used to determine the shear force. The Salter Warner-Bratzler Shear Mechanical Force machine was used to determine meat tenderness, expressed in $\mathrm{kg}$ force (kgf).

\section{Total intramuscular fat (IMF)}

The total intramuscular fat was quantified using the method of Bligh and Dyer (1959).

\section{Fatty acids composition}

The profile of meat fatty acids (FA) was determined using the extraction method by Folch et al. (1957) and the methyl esters were formed according to Kramer et al. (1997). The fatty acids were quantified using a gas chromatographer (GC-2010 Plus, Shimadzu AOC 20i auto-injector) with a SP-2560 capillary column $(100 \mathrm{~m} \times 0.25 \mathrm{~mm}$ in diameter with $0.02 \mathrm{~mm}$ thickness, Supelco, Bellefonte, PA, USA). Fatty acids were identified by comparison of the retention time of methyl esters of the samples with standards of fatty acids C4-C24 (F.A.M.E. Mix Sigma®), vaccenic acid: C18:1 t11 (V038-1G, Sigma®), CLA: C18:2 t10c12 (UC-61M 100 mg), CLA: C18:2 c9t11
(UC-60M $100 \mathrm{mg}$ ) and tricosanoic acid (Sigmaß). Fatty acids were quantified by normalising the area under the curve of methyl esters using the software GS solution 2.42. Fatty acids content were expressed as the percentage of total fatty acid methyl ester quantified.

Based on the identified acids, 25 FAs (18 individuals and seven groups of FAs) were selected due to their importance in relation to human health. The following fatty acids were determined: lauric (C12:0), myristic (C14:0), palmitic (C16:0), stearic (C18:0), myristoleic (C14:1), palmitoleic (C16:1), oleic (C18:1 c9), elaidic (C18:1 n9t), vaccenic (C18:1 t11), linoleic (C18:2 n6c), CLA-cis (C18:2 c9t11), CLA-trans (C18:2 t10c12), alpha-linolenic (C18:3 n3), gamma-linolenic (C18:3 n6), eicosatrienoic (C20:3 n6), eicosatrienoic (C20:3 $\mathrm{n} 3)$, arachidonic (20:4 n6) and docosahexaenoic (C22:6 n3). The sum of saturated $(\mathrm{C} 4: 0+\mathrm{C} 6: 0+\mathrm{C} 8: 0+\mathrm{C} 10: 0+\mathrm{C} 11: 0+$ $\mathrm{C} 12: 0+\mathrm{C} 13: 0+\mathrm{C} 14: 0+\mathrm{C} 15: 0+\mathrm{C} 16: 0+\mathrm{C} 17: 0+\mathrm{C} 18: 0+$ $\mathrm{C} 21: 0+\mathrm{C} 24: 0)$, monounsaturated $(\mathrm{C} 16: 1+\mathrm{C} 17: 1 \mathrm{c} 10+$ $\mathrm{C} 18: 1 \mathrm{t} 11+\mathrm{C} 15: 1 \mathrm{c} 10+\mathrm{C} 20: 1 \mathrm{c} 11+\mathrm{C} 24: 1+\mathrm{C} 22: 1 \mathrm{n} 9+$ $\mathrm{C} 18: 1 \mathrm{c} 9+\mathrm{C} 14: 1+18: 1 \mathrm{n} 7+\mathrm{C} 18: 1 \mathrm{n} 9 \mathrm{t})$, polyunsaturated $(\mathrm{C} 18: 2 \mathrm{n} 6+\mathrm{C} 18: 3 \mathrm{n} 3+\mathrm{C} 18: 3 \mathrm{n} 6+\mathrm{C} 20: 3 \mathrm{n} 3+\mathrm{C} 20: 3 \mathrm{n} 6+$ $\mathrm{C} 20: 4 \mathrm{n} 6+\mathrm{C} 20: 5 \mathrm{n} 3+\mathrm{C} 22: 6 \mathrm{n} 3)$, omega $6(\mathrm{C} 18: 3 \mathrm{n} 6+$ $\mathrm{C} 20: 3 \mathrm{n} 6+\mathrm{C} 18: 2 \mathrm{n} 6+\mathrm{C} 20: 4 \mathrm{n} 6)$ and omega $3(\mathrm{C} 18: 3 \mathrm{n} 3+$ $\mathrm{C} 20: 3 \mathrm{n} 3+\mathrm{C} 22: 6 \mathrm{n} 3+\mathrm{C} 20: 5 \mathrm{n} 3)$ fatty acids were calculated using the individual fatty acid concentration. The polyunsaturated/saturated (PUFA/SFA) fatty acids and omega 6/omega 3 (n-6/n-3) ratios were also calculated.

\section{Genotyping of animals}

A total of 1616 animals were genotyped using the BovineHD BeadChip (High-Density Bovine BeadChip, Illumina) with 777,962 single nucleotide polymorphisms (SNPs) markers. The SNPs markers excluded were those with unknown genomic position, located on sex chromosomes, monomorphic and markers with minor allele frequency (MAF) less than 0.05 , call rate less than $90 \%$ and markers with excess heterozygosity. Samples with call rate less than $90 \%$ were excluded, leaving genotypes for 470,007 SNPs from 1556 samples.

\section{Genetic-quantitative analysis}

The contemporary groups (CGs) included animals born on the same farm and in the same year, and from the same management group at yearling. The CGs with fewer than three records were eliminated from the analyses. Records exceeding three standard deviations above or below the mean of each CG were excluded. The model used for the (co)variance and genetic parameter estimation included the random genetic additive direct effect, the fixed effect of the $\mathrm{CG}$ and slaughter age as a covariable (linear and quadratic effect).

The (co)variances and genetic parameters were estimated using the restricted maximum likelihood method, using the 
remlf90 and airemlf90 software (Misztal et al. 2002) and considering an animal model (ssGBLUP). Initially, the remlf90 (EM-algorithm) software was applied until convergence was reached, then the (co)variance estimates obtained by remlf 90 software were utilised as starting values for the airemlf90 (AIalgorithm) software. The ssGBLUP model (single-step genomic BLUP) is a modification of BLUP with numerator relationship matrix $\mathrm{A}^{-1}$ replaced by $\mathrm{H}^{-1}$ (Aguilar et al. 2010):

$H^{-1}=A^{-1}+\left[\begin{array}{cc}0 & 0 \\ 0 & G^{-1}-A_{22}^{-1}\end{array}\right]$

where $A_{22}$ is a numerator relationship matrix for genotyped animals and $G$ is a genomic relationship matrix. The genomic matrix can be created as shown by VanRaden et al. (2009):

$G=Z D Z^{\prime} q$

where $Z$ is a matrix of gene content adjusted for allele frequencies, $D$ is a diagonal matrix and $q$ is a weighting/normalising factor. According to Vitezica et al. (2011), such a factor can be derived by ensuring that the average diagonal in $G$ is close to that of $A_{22}$. In order to decrease the computational demand and convergence problems, 25 multi-trait analyses, with four traits, were performed considering SF, BF and IMF plus each individual fatty acid or the proportion of SFA, MUFA, PUFA, n- $6, n-3$, PUFA/SFA and n- $6 / n-3$ ratios. For the traits, the model can be represented by the following matrix form:

$y=X \beta+Z a+e$

where $y$ is the vector of observations, $\beta$ the vector of fixed effects, $a$ the vector of direct additive genetic effects, $X$ the known incidence matrix, $Z$ the incidence matrix of the random additive direct genetic effect (associates vector $\beta$ with vector $y)$ and $e$ is the vector of the residual effect. It was assumed that $\mathrm{E}[\mathrm{y}]=\mathrm{Xb} ; \operatorname{Var}(\mathrm{a})=\mathrm{H} \otimes \mathrm{S}_{\mathrm{a}}$ and $\operatorname{Var}(\mathrm{e})=\mathrm{I} \otimes \mathrm{S}_{\mathrm{e}}$, where $\mathrm{S}_{\mathrm{a}}$ is the (co)variance matrix for the additive genetic effect, $\mathrm{S}_{\mathrm{e}}$ the (co)variance matrix for residual effect, $\mathrm{H}$ the relationship matrix, I the identity matrix and $\otimes$ is the Kronecker product.

As an alternative of standard error, the standard deviations of genetic parameters were calculated by repeated sampling of parameters estimates from their asymptotic multi-variate normal distribution, following the idea presented by Meyer and Houle (2013). The airemlf90 software (Misztal et al. 2002) has an option to estimate the standard deviation for the function of (co)variances (heritability and genetic correlations). The pedigree file contained the identifications of the animal, sire and dam, with a total of 2873 animals (after pruning) in the relationship matrix. The data file contained 1826 animals, including 131 sires and 899 cows with progeny presenting phenotypic data for at least one trait.

\section{Results and discussion}

The palmitic, stearic, oleic, linoleic and vaccenic acids showed the highest percentages in fat beef, which add up to $75.4 \%$ of total fatty acids found in the Longissimus thoracis (Table 1). The average percentages of C16:0, C18:0, oleic and linoleic acids found in this study were similar to those reported by Metz et al. (2009), Rossato et al. (2010), Nogi et al. (2011), Kelly et al. (2013) and Ekine-Dzivenu et al. (2014) for taurine breeds. Kelly et al. (2013), working with several taurine breeds, found an average of $3.33 \%$ for vaccenic acid, lower than that obtained in the present study.

In this study, palmitic and stearic saturated fatty acids were the most predominant. Palmitic acid is a medium-chain acid, which is not desirable in large amounts in meat, since it increases the serum levels of cholesterol and LDL, thus causing cardiovascular disease (Katan et al. 1994; Metz et al. 2009). However, stearic acid is important in the synthesis of unsaturated fatty acids, which are less harmful to human health because they are unstable. Despite its low concentration, myristic acid needs attention because it increases 4 to 6 times the concentration of serum cholesterol compared to palmitic acid (Mensink and Katan 1992).

The heritability estimates for saturated and polyunsaturated fatty acids ranged from low to high, varying from 0.06 to 0.65 , and were low for monounsaturated fatty acids, ranging from 0.02 to 0.23 . The CLA-cis acid had a heritability estimate lower than its isomer CLA-trans. The CLA-cis is a polyunsaturated fatty acid important to human health, since it increases the immune-stimulating, antioxidant and antimutagenic activities (Ip 1997). The CLA-cis isomer is the most biologically active form, due to its predominance in the phospholipids' membranes. Inoue et al. (2011) and Kelly et al. (2013) studied taurine breeds and obtained higher heritability estimates for most studied fatty acids compared to the present study. Recently, Cesar et al. (2014) estimated heritability for the fatty acid profile of intramuscular fat (Longissimus) in Nellore using two models (BayesB and GBLUP), and achieved moderate estimates for most FA.

Estimates of heritability for the sums of SFA, MUFA and PUFA corroborate to the study by Ekine-Dzivenu et al. (2014). The sums of MUFA and PUFA are considered beneficial to human health because they protect the cardiovascular system by decreasing the serum levels of cholesterol and increasing the high-density lipoproteins (HDL) (Pensel 1998; Tapiero et al. 2002). The HDL are responsible for reverse cholesterol transport by removing LDL excess left in the peripheral tissues and transporting it to the liver, where it is metabolised and eliminated from the body as acids and bile salts (Hirata and Hirata 2002). Essential fatty acids include the omega 3 and omega 6 families, which are not biologically synthesised by humans, but are necessary for biological processes and must, therefore, be ingested in the diet. The 
Table 1 Descriptive statistics, estimates of additive and residual variance, and heritability

$\left(h^{2}\right) \pm$ standard deviation (SD) for the fatty acid profiles, expressed as a percentage of total fatty acid methyl esters, in the Longissimus thoracis muscle from Nellore cattle

\begin{tabular}{|c|c|c|c|c|c|c|}
\hline Fatty acid $^{\mathrm{a}}$ & Nomenclature & $\mathrm{N}$ & Mean \pm SD & $\begin{array}{l}\text { Genetic } \\
\text { variance }\end{array}$ & $\begin{array}{l}\text { Residual } \\
\text { variance }\end{array}$ & $\mathrm{h}^{2} \pm \mathrm{SD}$ \\
\hline Lauric & $\mathrm{C} 12: 0$ & 538 & $0.06 \pm 0.18$ & 0.174 & 0.009 & $0.65 \pm 0.22$ \\
\hline Myristic & C14:0 & 867 & $2.13 \pm 0.54$ & 0.059 & 0.188 & $0.24 \pm 0.05$ \\
\hline Palmitic & $\mathrm{C} 16: 0$ & 867 & $20.9 \pm 2.54$ & 0.86 & 3.73 & $0.19 \pm 0.04$ \\
\hline Stearic & C18:0 & 783 & $13.6 \pm 3.31$ & 0.61 & 9.16 & $0.06 \pm 0.01$ \\
\hline Myristoleic & C14:1 & 824 & $0.31 \pm 0.22$ & 0.006 & 0.036 & $0.14 \pm 0.09$ \\
\hline Palmitoleic & $\mathrm{C} 16: 1$ & 937 & $2.18 \pm 0.78$ & 0.058 & 0.58 & $0.09 \pm 0.03$ \\
\hline Oleic & C18:1 c9 & 934 & $30.64 \pm 4.98$ & 1.67 & 86.89 & $0.02 \pm 0.003$ \\
\hline Elaidic & $\mathrm{C} 18: 1 \mathrm{n} 9 \mathrm{t}$ & 483 & $2.9 \pm 5.06$ & 2.06 & 17.18 & $0.10 \pm 0.01$ \\
\hline Vaccenic & C18:1 t11 & 878 & $1.29 \pm 0.94$ & 0.82 & 45.95 & $0.02 \pm 0.001$ \\
\hline Linoleic & $\mathrm{C} 18: 2 \mathrm{n} 6 \mathrm{c}$ & 865 & $8.40 \pm 3.70$ & 0.89 & 5.97 & $0.13 \pm 0.03$ \\
\hline Alpha-linolenic & $\mathrm{C} 18: 3 \mathrm{n} 3$ & 858 & $0.59 \pm 0.26$ & 0.004 & 0.002 & $0.68 \pm 0.04$ \\
\hline Gamma-linolenic & C18:3 n6 & 569 & $0.08 \pm 0.07$ & 0.005 & 0.032 & $0.12 \pm 0.02$ \\
\hline Eicosatrienoic & C20:3 n6 & 862 & $0.49 \pm 0.20$ & 0.002 & 0.030 & $0.07 \pm 0.03$ \\
\hline Eicosatrienoic & $\mathrm{C} 20: 3 \mathrm{n} 3$ & 862 & $2.00 \pm 0.76$ & 0.043 & 0.452 & $0.09 \pm 0.03$ \\
\hline Arachidonic & C20:4 n6 & 432 & $1.11 \pm 3.13$ & 0.268 & 7.314 & $0.05 \pm 0.01$ \\
\hline Docosahexaenoic & $\mathrm{C} 22: 6 \mathrm{n} 3$ & 865 & $0.95 \pm 0.38$ & 0.014 & 0.106 & $0.12 \pm 0.09$ \\
\hline CLA-cis & C18:2 c9t11 & 727 & $0.26 \pm 0.11$ & 0.0006 & 0.0065 & $0.08 \pm 0.05$ \\
\hline CLA-trans & $\mathrm{C} 18: 2 \mathrm{t} 10 \mathrm{c} 12$ & 241 & $0.20 \pm 0.12$ & 0.003 & 0.004 & $0.57 \pm 0.07$ \\
\hline SFA sum & & 868 & $40.6 \pm 6.03$ & 2.57 & 26.10 & $0.09 \pm 0.01$ \\
\hline MUFA sum & & 868 & $37.4 \pm 8.12$ & 28.096 & 21.323 & $0.10 \pm 0.03$ \\
\hline PUFA sum & & 868 & $13.5 \pm 5.67$ & 4.07 & 16.05 & $0.20 \pm 0.02$ \\
\hline PUFA/SFA ratio & & 868 & $0.35 \pm 0.20$ & 0.002 & 0.028 & $0.07 \pm 0.06$ \\
\hline Omega 3 & $\mathrm{n}-3$ & 868 & $3.78 \pm 1.55$ & 0.150 & 1,83 & $0.08 \pm 0.03$ \\
\hline Omega 6 & $\mathrm{n}-6$ & 868 & $9.46 \pm 4.54$ & 2.16 & 9.91 & $0.18 \pm 0.03$ \\
\hline n-6/n-3 ratio & & 868 & $2.58 \pm 0.98$ & 0.055 & 0.63 & $0.08 \pm 0.02$ \\
\hline
\end{tabular}

The concentrations of fatty acids are expressed as a percentage of total fatty acid methyl esters (FAME) quantified ${ }^{\mathrm{a}} \mathrm{SFA}$ sum $(\mathrm{C} 4: 0+\mathrm{C} 6: 0+\mathrm{C} 8: 0+\mathrm{C} 10: 0+\mathrm{C} 11: 0+\mathrm{C} 12: 0+\mathrm{C} 13: 0+\mathrm{C} 14: 0+\mathrm{C} 15: 0+\mathrm{C} 16: 0+\mathrm{C} 17: 0+\mathrm{C} 18: 0+$ $\mathrm{C} 21: 0+\mathrm{C} 24: 0)$; MUFA sum $(\mathrm{C} 16: 1+\mathrm{C} 17: 1 \mathrm{c} 10+\mathrm{C} 18: 1 \mathrm{t} 11+\mathrm{C} 15: 1 \mathrm{c} 10+\mathrm{C} 20: 1 \mathrm{c} 11+\mathrm{C} 24: 1+\mathrm{C} 22: 1 \mathrm{n} 9+$ $\mathrm{C} 18: 1 \mathrm{c} 9+\mathrm{C} 14: 1+18: 1 \mathrm{n} 7+\mathrm{C} 18: 1 \mathrm{n} 9 \mathrm{t}) ;$ PUFA sum $(\mathrm{C} 18: 2 \mathrm{n} 6+\mathrm{C} 18: 3 \mathrm{n} 3+\mathrm{C} 18: 3 \mathrm{n} 6+\mathrm{C} 20: 3 \mathrm{n} 3+\mathrm{C} 20: 3 \mathrm{n} 6+$ $\mathrm{C} 20: 4 \mathrm{n} 6+\mathrm{C} 20: 5 \mathrm{n} 3+\mathrm{C} 22: 6 \mathrm{n} 3) ; \mathrm{n}-6(\mathrm{C} 18: 3 \mathrm{n} 6+\mathrm{C} 20: 3 \mathrm{n} 6+\mathrm{C} 18: 2 \mathrm{n} 6+\mathrm{C} 20: 4 \mathrm{n} 6)$ and n-3 (C18:3 n3 + C20:3 $\mathrm{n} 3+\mathrm{C} 22: 6 \mathrm{n} 3+\mathrm{C} 20: 5 \mathrm{n} 3)$ omega 3 and omega 6 fatty acids have low and moderate heritability estimates, 0.08 and 0.19 , respectively. Cesar et al. (2014) obtained moderate heritability estimates for omega $3(0.17)$ and omega $6(0.15)$ in Nellore beef. The results of this study allow us to conclude that it is possible to obtain response to selection for the composition of the intramuscular fat in zebu animals, despite some low heritability estimates.

The mean shear force obtained is above the tenderness acceptable range of 4.7-5.0 kgf (Table 2). The average SF obtained in this study is close to the values reported by Crouse et al. (1989), Burrow et al. (2001), Schutt et al. (2009) and Pinto et al. (2010) for Bos indicus beef and their crossbreds with different proportions of Bos taurus. In our study, the mean percentage of lipids in the Longissimus thoracis muscle was lower than the values reported by Charles and Johnson (1976), Holloway et al. (1990), HuertaLeidenz et al. (1996), Newman et al. (2002) and Cesar et al.
(2014) for Bos taurus, Bos indicus and their crossbreds, also finished in feedlot. The mean for BF obtained in this study was lower than the values reported by Silva et al. (2003), Rubiano et al. (2009) and Pereira et al. (2014) for Nelore finished in feedlot as well. The mean SF, IMF and BF values obtained in this study show that the acceptability of the meat is compromised in some international consumer markets, requiring greater juiciness, tenderness and flavour. However, it has characteristics that are beneficial to human health, such as low content of intramuscular fat and a fatty acids profile with high levels of the n-3 series and an adequate dietary quality based on the $n-6 / n-3$ and PUFA/SFA ratios (Table 1 ).

The carcass and meat traits, SF and IMF, had low heritability estimates, while BF was moderate (Table 2). The BF heritability estimate was lower than the estimates found in the literature for zebu animals, which range from 0.36 to 0.63 (Riley et al. 2002; Smith et al. 2007). Riley et al. 
Table 2 Descriptive statistics, estimates of additive and residual genetic variance, and heritability $\left(\mathrm{h}^{2}\right) \pm$ standard deviation (SD) for the carcass and meat traits

\begin{tabular}{llllll}
\hline Trait $^{\mathrm{a}}$ & $\mathrm{N}$ & Mean $\pm \mathrm{SD}$ & $\begin{array}{l}\text { Genetic } \\
\text { variance }\end{array}$ & $\begin{array}{l}\text { Residual } \\
\text { variance }\end{array}$ & $\mathrm{h}^{2} \pm \mathrm{SD}$ \\
\hline $\mathrm{BF}$ & 1564 & $4.02 \pm 2.7$ & 0.48 & 3.22 & $0.17 \pm 0.02$ \\
$\mathrm{SF}$ & 1826 & $5.17 \pm 1.4$ & 0.067 & 1.18 & $0.06 \pm 0.01$ \\
$\mathrm{IMF}$ & 1812 & $0.82 \pm 0.42$ & 0.033 & 0.065 & $0.07 \pm 0.01$ \\
\hline
\end{tabular}

${ }^{\text {a }} \mathrm{BF}$ : subcutaneous fat thickness (mm) measured between the 12th and 13th ribs; IMF: total intramuscular fat (\%) in the Longissimus thoracis muscle; SF: shear force (kgf) measured in the Longissimus thoracis
(2002) and Smith et al. (2007) showed higher heritability estimates for marbling in Bos indicus, 0.37 and 0.44, respectively. The heritability estimated for SF was similar to the values found in the literature (Riley et al. 2002; Smith et al. 2007). It is expected that the response to improve the carcass subcutaneous fat thickness by selection would be higher than those traits related to meat tenderness and intramuscular fat content.

Estimates of genetic correlations between carcass and meat traits with the saturated fatty acid profile are displayed in Table 3. The estimates of genetic correlation between subcutaneous fat thickness and the saturated fatty acids were low to moderate, ranging from -0.13 to 0.60 . With the exception of the lauric fatty acid, estimates of genetic correlations between saturated fatty acids and beef tenderness were low. Kelly et al. (2013) studied taurine and adapted tropical breeds and obtained low genetic correlation estimates between fat thickness at P8 with C14:0 $(-0.19)$ and C16:0 $(-0.21)$ and a moderate estimate for C18:0 (-0.46).

Table 3 Estimates of genetic correlations \pm standard deviation (SD) between saturated fatty acids and the carcass and meat traits

\begin{tabular}{|c|c|c|c|}
\hline Saturated fatty acids & Nomenclature & Traits $^{\mathrm{a}}$ & $\mathrm{r}_{\mathrm{a}} \pm \mathrm{SD}$ \\
\hline \multirow[t]{3}{*}{ Lauric } & \multirow[t]{3}{*}{$\mathrm{C} 12: 0$} & $\mathrm{BF}$ & $0.04 \pm 0.42$ \\
\hline & & $\mathrm{SF}$ & $-0.53 \pm 0.45$ \\
\hline & & IMF & $0.35 \pm 0.88$ \\
\hline \multirow[t]{3}{*}{ Myristic } & \multirow[t]{3}{*}{$\mathrm{C} 14: 0$} & $\mathrm{BF}$ & $0.40 \pm 0.15$ \\
\hline & & $\mathrm{SF}$ & $0.16 \pm 0.18$ \\
\hline & & IMF & $0.76 \pm 0.09$ \\
\hline \multirow[t]{3}{*}{ Palmitic } & \multirow[t]{3}{*}{ C16:0 } & $\mathrm{BF}$ & $0.60 \pm 0.12$ \\
\hline & & $\mathrm{SF}$ & $-0.08 \pm 0.21$ \\
\hline & & IMF & $0.79 \pm 0.08$ \\
\hline \multirow[t]{3}{*}{ Stearic } & \multirow[t]{3}{*}{ C18:0 } & $\mathrm{BF}$ & $-0.13 \pm 0.13$ \\
\hline & & SF & $0.05 \pm 0.14$ \\
\hline & & IMF & $0.68 \pm 0.08$ \\
\hline \multirow[t]{3}{*}{ SFA sum ${ }^{b}$} & & $\mathrm{BF}$ & $0.04 \pm 0.08$ \\
\hline & & $\mathrm{SF}$ & $0.29 \pm 0.07$ \\
\hline & & IMF & $0.24 \pm 0.07$ \\
\hline
\end{tabular}

${ }^{a} \mathrm{BF}$ : subcutaneous fat thickness (mm) measured between the 12 th and 13th ribs; IMF: total intramuscular fat (\%) in the Longissimus thoracis muscle; SF: shear force (kgf) measured in the Longissimus thoracis

${ }^{\mathrm{b}}$ SFA sum $(\mathrm{C} 4: 0+\mathrm{C} 6: 0+\mathrm{C} 8: 0+\mathrm{C} 10: 0+\mathrm{C} 11: 0+\mathrm{C} 12: 0+\mathrm{C} 13: 0+$ $\mathrm{C} 14: 0+\mathrm{C} 15: 0+\mathrm{C} 16: 0+\mathrm{C} 17: 0+\mathrm{C} 18: 0+\mathrm{C} 21: 0+\mathrm{C} 24: 0)$
The total intramuscular fat in the Longissimus thoracis muscle (IMF) had low genetic correlation estimates with sum of SFA, moderate with lauric, myristic and stearic acids, and high with palmitic acid. Genetic correlations between carcass and meat traits with saturated fatty acids indicate that selection to increase the deposition of subcutaneous fat, especially the percentage of lipids in the Longissimus thoracis muscle, would probably change the percentage of saturated fatty acids in the meat in the same direction. However, our results showed that selection to improve the beef tenderness will not result in major changes in the content of saturated fatty acids in the intramuscular fat in the Longissimus thoracis muscle.

Estimates of genetic correlations between carcass and meat traits with the monounsaturated fatty acids profile are shown in Table 4. The genetic correlations estimated for the monounsaturated fatty acids ranged from low to high magnitude, between near-zero values to 0.90 . With the exception of myristoleic, palmitoleic and elaidic acids, the other acids had low correlation estimates with the meat tenderness. Estimates of genetic correlations between monounsaturated fatty acids with BF were moderate, except for oleic and palmitoleic acid. Nogi et al. (2011) worked with taurine breeds and estimated low genetic correlation $(0.16)$ between the subcutaneous fat thickness (BF) with MUFA. Kelly et al. (2013) studied taurine and adapted tropical breeds and reported a moderate genetic association (0.56) between fat thickness at P8 with oleic fatty acid content in the subcutaneous fat. Chung et al. (2007) and Brooks et al. (2011) stated that, as the animal degree of termination increases during confinement, so does the activity of the SCD gene, with consequent increase in oleic acid content. However, in this study, there was a genetic antagonism between the oleic acid content and the fat thickness. Probably, the fact that the fatty acid profile was determined in the intramuscular fat of the Longissimus thoracis muscle might explain these differences.

Estimates of genetic correlations between the percentages of lipids in the muscle with monounsaturated fatty acids varied from positive and moderate to high, with the exception of oleic acid. Therefore, it is expected that selection to increase the level of intramuscular fat in the Longissimus thoracis muscle should also increase the content of monounsaturated fatty acids. Likewise, Inoue et al. (2011) also correlated meat 
Table 4 Estimates of the genetic $\left(\mathrm{r}_{\mathrm{a}}\right)$ correlation \pm standard deviation (SD) between the monounsaturated fatty acids and the carcass and meat traits

\begin{tabular}{|c|c|c|c|}
\hline $\begin{array}{l}\text { Monounsaturated } \\
\text { fatty acids }\end{array}$ & Nomenclature & Traits $^{\mathrm{a}}$ & $\mathrm{r}_{\mathrm{a}} \pm \mathrm{SD}$ \\
\hline \multirow[t]{3}{*}{ Myristoleic } & \multirow[t]{3}{*}{$\mathrm{C} 14: 1$} & $\mathrm{BF}$ & $0.33 \pm 0.13$ \\
\hline & & $\mathrm{SF}$ & $-0.57 \pm 0.18$ \\
\hline & & IMF & $0.51 \pm 0.16$ \\
\hline \multirow[t]{3}{*}{ Palmitoleic } & \multirow[t]{3}{*}{$\mathrm{C} 16: 1$} & $\mathrm{BF}$ & $0.15 \pm 0.21$ \\
\hline & & $\mathrm{SF}$ & $-0.68 \pm 0.18$ \\
\hline & & IMF & $0.50 \pm 0.20$ \\
\hline \multirow[t]{3}{*}{ Oleic } & \multirow[t]{3}{*}{ C18:1 c9 } & $\mathrm{BF}$ & $-0.04 \pm 0.10$ \\
\hline & & $\mathrm{SF}$ & $0.08 \pm 0.09$ \\
\hline & & IMF & $0.05 \pm 0.10$ \\
\hline \multirow[t]{3}{*}{ Elaidic } & \multirow[t]{3}{*}{$\mathrm{C} 18: 1 \mathrm{n} 9 \mathrm{t}$} & $\mathrm{BF}$ & $0.64 \pm 0.06$ \\
\hline & & $\mathrm{SF}$ & $-0.47 \pm 0.08$ \\
\hline & & IMF & $0.41 \pm 0.09$ \\
\hline \multirow[t]{3}{*}{ Vaccenic } & \multirow[t]{6}{*}{$\mathrm{C} 18: 1 \mathrm{t} 11$} & $\mathrm{BF}$ & $0.40 \pm 0.12$ \\
\hline & & $\mathrm{SF}$ & $-0.07 \pm 0.14$ \\
\hline & & IMF & $0.45 \pm 0.11$ \\
\hline \multirow[t]{3}{*}{ MUFA sum ${ }^{b}$} & & $\mathrm{BF}$ & $0.64 \pm 0.15$ \\
\hline & & $\mathrm{SF}$ & $-0.06 \pm 0.42$ \\
\hline & & IMF & $0.90 \pm 0.06$ \\
\hline
\end{tabular}

${ }^{a} \mathrm{BF}$ : subcutaneous fat thickness (mm) measured between the 12th and 13th ribs; IMF: total intramuscular fat (\%) in the Longissimus thoracis muscle; SF: shear force (kgf) measured in the Longissimus thoracis

${ }^{\mathrm{b}}$ MUFA sum $(\mathrm{C} 16: 1+\mathrm{C} 17: 1 \mathrm{c} 10+\mathrm{C} 18: 1 \mathrm{t} 11+\mathrm{C} 15: 1 \mathrm{c} 10+\mathrm{C} 20: 1$

$\mathrm{c} 11+\mathrm{C} 24: 1+\mathrm{C} 22: 1 \mathrm{n} 9+\mathrm{C} 18: 1 \mathrm{c} 9+\mathrm{C} 14: 1+18: 1 \mathrm{n} 7+\mathrm{C} 18: 1 \mathrm{n} 9 \mathrm{t})$

marbling level with some fatty acids in the meat of the Japanese Black breeds, and reported a high estimate for the genetic correlation (0.96) with the summation (MUFA).

Estimates of genetic correlations between the polyunsaturated fatty acid profile, omega 3 and omega 6 with subcutaneous fat thickness were mostly low (Table 5). The estimates of genetic correlations between SF and individual polyunsaturated fatty acids varied in magnitude and sign. With the exception of alpha-linolenic and CLA-cis, the estimates of genetic correlation between lipids percentage in the Longissimus thoracis muscle with the individual fatty acids level, sum of PUFA and PUFA/SFA ratio were negative, and varied from moderate to high. Similar results were obtained for the omega 3 , omega 6 and omega6/omega 3 ratio. Therefore, the results of this study allow inferring that the selection to increase the deposition of intramuscular fat should promote an unfavourable decrease in polyunsaturated fatty acid levels, omega 3 and omega 6. Nogi et al. (2011) investigated the Japanese Black breed and estimated moderate genetic correlations, ranging from 0.30 to 0.39 , between the rib eye area, fat thickness and meat yield with the content of linoleic fatty acid, PUFA and PUFA/SFA ratio in the Longissimus muscle. The same authors also reported near-zero genetic correlations
Table 5 Estimates of the genetic $\left(r_{a}\right)$ correlation \pm standard deviation (SD) between the CLA-cis, CLA-trans, PUFA, omega 3 and 6, and PUFA/SFA ratio with the carcass and meat traits

\begin{tabular}{|c|c|c|c|}
\hline $\begin{array}{l}\text { Polyunsaturated } \\
\text { fatty acids }\end{array}$ & Nomenclature & Traits $^{\mathrm{a}}$ & $\mathrm{r}_{\mathrm{a}} \pm \mathrm{SD}$ \\
\hline \multirow[t]{3}{*}{ Alpha-linolenic } & \multirow[t]{3}{*}{$\mathrm{C} 18: 3 \mathrm{n} 3$} & $\mathrm{BF}$ & $-0.01 \pm 0.05$ \\
\hline & & SF & $-0.26 \pm 0.05$ \\
\hline & & IMF & $0.55 \pm 0.05$ \\
\hline \multirow[t]{3}{*}{ Linoleic } & \multirow[t]{3}{*}{$\mathrm{C} 18: 2 \mathrm{n} 6 \mathrm{c}$} & $\mathrm{BF}$ & $0.10 \pm 0.14$ \\
\hline & & $\mathrm{SF}$ & $-0.03 \pm 0.13$ \\
\hline & & $\mathrm{IMF}$ & $-0.91 \pm 0.05$ \\
\hline \multirow[t]{3}{*}{ Gamma-linolenic } & \multirow[t]{3}{*}{ C18:3 n6 } & $\mathrm{BF}$ & $0.22 \pm 0.12$ \\
\hline & & SF & $-0.37 \pm 0.12$ \\
\hline & & IMF & $-0.55 \pm 0.11$ \\
\hline \multirow[t]{3}{*}{ Eicosatrienoic } & \multirow[t]{3}{*}{$\mathrm{C} 20: 3 \mathrm{n} 6$} & $\mathrm{BF}$ & $-0.33 \pm 0.19$ \\
\hline & & $\mathrm{SF}$ & $-0.08 \pm 0.25$ \\
\hline & & IMF & $-0.69 \pm 0.15$ \\
\hline \multirow[t]{3}{*}{ Eicosatrienoic } & \multirow[t]{3}{*}{$\mathrm{C} 20: 3 \mathrm{n} 3$} & $\mathrm{BF}$ & $-0.33 \pm 0.19$ \\
\hline & & $\mathrm{SF}$ & $-0.08 \pm 0.26$ \\
\hline & & IMF & $-0.69 \pm 0.15$ \\
\hline \multirow[t]{3}{*}{ Docosahexaenoic } & \multirow[t]{3}{*}{$\mathrm{C} 22: 6 \mathrm{n} 3$} & $\mathrm{BF}$ & $-0.30 \pm 0.20$ \\
\hline & & SF & $-0.10 \pm 0.28$ \\
\hline & & IMF & $-0.50 \pm 0.16$ \\
\hline \multirow[t]{3}{*}{ Arachidonic } & \multirow[t]{3}{*}{ C20:4 n6 } & $\mathrm{BF}$ & $-0.68 \pm 0.08$ \\
\hline & & $\mathrm{SF}$ & $0.13 \pm 0.15$ \\
\hline & & IMF & $-0.92 \pm 0.05$ \\
\hline \multirow[t]{3}{*}{ CLA-cis } & \multirow[t]{3}{*}{$18: 2$ c9t11 } & $\mathrm{BF}$ & $0.16 \pm 0.42$ \\
\hline & & SF & $-0.53 \pm 0.70$ \\
\hline & & IMF & $0.16 \pm 0.59$ \\
\hline \multirow[t]{3}{*}{ CLA-trans } & \multirow[t]{3}{*}{$18: 2 \mathrm{t} 10 \mathrm{c} 12$} & $\mathrm{BF}$ & $-0.10 \pm 0.08$ \\
\hline & & $\mathrm{SF}$ & $0.59 \pm 0.16$ \\
\hline & & IMF & $-0.75 \pm 0.50$ \\
\hline \multirow{3}{*}{ Omega $3^{\mathrm{b}}$} & \multirow[t]{3}{*}{$\mathrm{n}-3$} & $\mathrm{BF}$ & $-0.18 \pm 0.23$ \\
\hline & & $\mathrm{SF}$ & $-0.36 \pm 0.27$ \\
\hline & & IMF & $-0.39 \pm 0.23$ \\
\hline \multirow{3}{*}{ Omega $6^{\mathrm{c}}$} & \multirow[t]{3}{*}{$n-6$} & $\mathrm{BF}$ & $-0.37 \pm 0.09$ \\
\hline & & SF & $0.07 \pm 0.13$ \\
\hline & & IMF & $-0.84 \pm 0.05$ \\
\hline \multirow[t]{3}{*}{ n-6/n-3 ratio } & & $\mathrm{BF}$ & $-0.30 \pm 0.18$ \\
\hline & & SF & $0.68 \pm 0.13$ \\
\hline & & IMF & $-0.84 \pm 0.08$ \\
\hline \multirow[t]{3}{*}{ PUFA sum ${ }^{d}$} & & $\mathrm{BF}$ & $-0.41 \pm 0.07$ \\
\hline & & $\mathrm{SF}$ & $0.22 \pm 0.10$ \\
\hline & & IMF & $-0.53 \pm 0.08$ \\
\hline \multirow[t]{3}{*}{ PUFA/SFA ratio } & & $\mathrm{BF}$ & $-0.36 \pm 0.46$ \\
\hline & & $\mathrm{SF}$ & $-0.04 \pm 0.21$ \\
\hline & & IMF & $-0.67 \pm 0.10$ \\
\hline
\end{tabular}

${ }^{\mathrm{a}} \mathrm{BF}$ : subcutaneous fat thickness $(\mathrm{mm})$ measured between the 12 th and 13th ribs; IMF: total intramuscular fat (\%) in the Longissimus thoracis muscle; SF: shear force (kgf) measured in the Longissimus thoracis

${ }^{\mathrm{b}} \mathrm{n}-3(\mathrm{C} 18: 3 \mathrm{n} 3+\mathrm{C} 20: 3 \mathrm{n} 3+\mathrm{C} 22: 6 \mathrm{n} 3+\mathrm{C} 20: 5 \mathrm{n} 3)$

${ }^{\mathrm{c}} \mathrm{n}-6(\mathrm{C} 18: 3 \mathrm{n} 6+\mathrm{C} 20: 3 \mathrm{n} 6+\mathrm{C} 18: 2 \mathrm{n} 6+\mathrm{C} 20: 4 \mathrm{n} 6)$

${ }^{\mathrm{d}}$ PUFA sum $(\mathrm{C} 18: 2 \mathrm{n} 6+\mathrm{C} 18: 3 \mathrm{n} 3+\mathrm{C} 18: 3 \mathrm{n} 6+\mathrm{C} 20: 3 \mathrm{n} 3+\mathrm{C} 20: 3 \mathrm{n} 6+$ $\mathrm{C} 20: 4 \mathrm{n} 6+\mathrm{C} 20: 5 \mathrm{n} 3+\mathrm{C} 22: 6 \mathrm{n} 3)$

between marbling score and linoleic fatty acid content, PUFA and PUFA/SFA ratio in the Longissimus muscle.

For international meat quality standards, the amount of intramuscular fat or marbling deposited in the Longissimus muscle determines the carcass value and it is a good predictor of meat palatability (Tatum et al. 1982). The results of this study and other studies indicate that zebu breeds 
have a lower content of intramuscular fat compared to taurine breeds, which results in changing palatability, flavour, juiciness and tenderness, and may, therefore, influence meat acceptability by the consumers. The results of this study indicate that selection to increase the level of intramuscular fat in the Longissimus thoracis muscle should decrease the content of polyunsaturated fatty acids and the omega 3 and omega 6 series, and increase the levels of saturated and monounsaturated fatty acids, thus decreasing the dietary and nutritional quality of the meat. De Smet et al. (2004) and Wood et al. (2008) stated that, as animal fat increases, the proportion of PUFA in the meat decreases drastically. Desirable attributes of the meat improve as the level of fat in the carcass increases, and there is an inverse relationship between nutritional value and the acceptability of the meat in ruminants (Wood et al. 2008).

The beef tenderness is an attribute that needs to be improved in zebu breeds, since it can restrict meat access to important markets and decrease the value of the product. However, the meat of Zebu breeds is nutritionally healthier compared to the meat of taurine breeds, and when consumed in moderate amounts, should not cause problems to human health (Huerta-Leidenz et al. 1993, 1996; Perry et al. 1998; Rossato et al. 2010). The results of this study indicated that selection to improve meat tenderness in the Longissimus thoracis muscle should not change the meat fatty acid profile and its nutritional value in Nellore breed.

The subcutaneous fat thickness is critical in the postslaughter process because it prevents the shortening of muscle fibres, called cold-shortening; darkening and stiffening of the meat. This process is commonly observed in meat of animals slaughtered with low fat thickness, and a characteristic of the zebu breeds, which have little body fat coverage (Burrow et al. 2001; Silva et al. 2003; Rubiano et al. 2009; Pereira et al. 2014). Estimates of genetic correlations between the fatty acid profile and fat thickness varied in magnitude and sign, unlike the results for intramuscular fat level in the Longissimus thoracis, and were mostly low with saturated and polyunsaturated fatty acids, and moderate with monounsaturated fatty acids. Therefore, the selection to increase body fat should increase the levels of most individual monounsaturated fatty acids and MUFA sum, with the exception of oleic acid. In this study, the fatty acid profile was obtained from the intramuscular fat in the Longissimus thoracis muscle, which might explain the stronger association between fat composition and the percentage of intramuscular fat in relation to subcutaneous fat thickness. Moreover, the growth of different tissues in animals is allometric, e.g. subcutaneous fat grows earlier compared to intramuscular fat, and, therefore, it is expected that both tissues exhibit different fatty acids profile since they are indifferent physiological states as well.

The fatty acid profile of the meat is a trait that is difficult and costly to measure, unlike the carcass and meat traits, which are easier to obtain. It is, therefore, very important to identify the indicator traits that are associated with the fatty acid profile. The results obtained in this study indicate that the percentage of intramuscular fat in the Longissimus thoracis muscle can be used as the indicator trait of the fatty acid profile of zebu meat. However, before fatty acid composition can be included in breeding programmes, more information on the relationship between the fatty acids composition and other production traits, such as growth and reproduction characteristics as well as economic indicators, need to be determined.

In Brazil, carcass and meat traits, and especially meat fatty acid profile, have not been used yet by the meat industry as a criterion for determining the value of animals for slaughter. However, the international markets of meat products have shown an increasing tendency to provide technical and scientific guarantees as a certification of food safety, product quality and its benefits to human health. Therefore, information is key to promote and improve worldwide marketing of meat products. The few studies available in the literature on the genetic association between the fatty acid profile of the meat and carcass and meat traits in cattle were performed with taurine breeds under temperate conditions. These results are unprecedented, as it is the first study of genetic association between these traits with Bos indicus under tropical conditions, and provides data that can be used to improve beef quality and produce healthier food for the consumer. This study used a large database of animals that participate in different genetic improvement programmes of beef cattle, and breeders that are commercialised in various regions of the country. Therefore, the information obtained should contribute to improving the selection and breeding programmes of meat quality of zebu cattle raised in tropical conditions.

\section{Conclusion}

The selection to improve meat tenderness in Nellore cattle should not change the fatty acid composition in beef, so it is possible to improve this attribute without affecting the nutritional beef quality in zebu breeds. However, selection for increased deposition of subcutaneous fat thickness and especially the percentage of intramuscular fat should lead to changes in the fat composition, highlighting a genetic antagonism between meat nutritional value and acceptability by the consumer. 
Acknowledgements This research was supported by the Sao Paulo Research Foundation (2009/16118-5, 2011/21241-0 and 2012/23979-0).

\section{Compliance with ethical standards}

Ethical approval All procedures performed in studies involving animals were in accordance with the ethical standards of the Faculty of Agrarian and Veterinarian Science, Sao Paulo State University (UNESP).

\section{References}

Aguilar I, Misztal I, Johnson DL, Legarra A, Tsuruta S, Lawlor TJ (2010) Hot topic: a unified approach to utilize phenotypic, full pedigree, and genomic information for genetic evaluation of Holstein final score. J Dairy Sci 93(2):743-752

Becker N, Illingworth DR, Alaupovic P, Connor WE, Sundberg EE (1983) Effects of saturated, monounsaturated, and omega-6 polyunsaturated fatty acids on plasma lipids, lipoproteins, and apoproteins in humans. Am J Clin Nutr 37:355-360

Bligh EG, Dyer WJ (1959) A rapid method of total lipid extraction and purification. Can J Biochem Physiol 37:911-917

Brooks MA, Choi CW, Lunt DK, Kawachi H, Smith SB (2011) Subcutaneous and intramuscular adipose tissue stearoyl-coenzyme A desaturase gene expression and fatty acid composition in calf- and yearling-fed Angus steers. J Anim Sci 89:2556-2570

Burrow HM, Moore SS, Johnston DJ, Barendse W, Bindon BM (2001) Quantitative and molecular genetic influences on properties of beef: a review. Aust J Exp Agric 41:893-919

Cesar ASM, Regitano LCA, Mourão GB, Tullio RR, Lanna DPD, Nassu RT et al (2014) Genome-wide association study for intramuscular fat deposition and composition in Nellore cattle. BMC Genet 15:39

Charles DD, Johnson ER (1976) Breed differences in amount and distribution of bovine carcass dissectible fat. J Anim Sci 42:332-341

Chung KY, Lunt DK, Kawachi H, Yano H, Smith SB (2007) Lipogenesis and stearoyl-CoA desaturase gene expression and enzyme activity in adipose tissue of short- and long-fed Angus and Wagyu steers fed corn- or hay-based diets. J Anim Sci 85:380-387

Crouse JD, Cundiff LV, Koch RM, Koohmaraie M, Seideman SC (1989) Comparisons of and inheritance for carcass beef characteristics and meat palatability. J Anim Sci 67:2661-2668

Cundiff LV (2004) Beef cattle: breeds and genetics. In: Pond WG, Bell AW (eds) Encyclopedia of animal science. Cornell University, Ithaca, pp 800-830

De Smet S, Raes K, Demeyer D (2004) Meat fatty acid composition as affected by fatness and genetic factors: a review. Anim Res EDP Sci 53(2):81-98

Ekine-Dzivenu C, Chen L, Vinsky M, Aldai N, Dugan MER, Mcallister TA et al (2014) Estimates of genetic parameters for fatty acids in brisket adipose tissue of Canadian commercial crossbred beef steers. Meat Sci 96:1517-1526

Folch J, Lees M, Sloane-Stanley GH (1957) A simple method for the isolation and purification of total lipids from animal tissues. J Biol Chem 226:497-509

French P, O'Riordan EG, Monahan FJ, Caffrey PJ, Vidal M, Mooney MT et al (2000) Meat quality of steers finished on autumn grass, grass silage or concentrate-based diets. Meat Sci 56:173-180

Givens DI (2005) The role of animal nutrition in improving the nutritive value of animal-derived foods in relation to chronic disease. Proc Nutr Soc 64:395-402

Hirata MH, Hirata RDC (2002) Transporte de ácidos graxos no plasma. In: Curi R, Pompéia C, Miyasaka CK, Procópio J (eds) Entendendo a gordura: ácidos graxos. Barueri, São Paulo, pp 61-72
Holloway JW, Savell JW, Hamby PL, Baker JF, Stouffer JR (1990) Relationships of empty-body composition and fat distribution to live animal and carcass measurements in Bos indicus-Bos taurus crossbred cows. J Anim Sci 68(7):1818-1826

Huerta-Leidenz NO, Cross HR, Savell JW, Lunt DK, Baker JF, Pelton LS et al (1993) Comparison of the fatty acid composition of subcutaneous adipose tissue from mature Brahman and Hereford cows. J Anim Sci 71:625-630

Huerta-Leidenz NO, Cross HR, Savell JW, Lunt DK, Baker JF, Smith SB (1996) Fatty acid composition of subcutaneous adipose tissue from male calves at different stages of growth. J Anim Sci 74:1256-1264

Inoue K, Kobayashi M, Shoji N, Kato K (2011) Genetic parameters for fatty acid composition and feed efficiency traits in Japanese Black cattle. Animal 5:987-994

Ip C (1997) Review of the effects of trans fatty acids, oleic acid, n-3 polyunsaturated fatty acids, and conjugated linoleic acid on mammary carcinogenesis in animals. Am J Clin Nutr 66:1523S-1529S

Katan MB, Zock PL, Mensink RP (1994) Effects of fats and fatty acids on blood lipids in humans: an overview. Am J Clin Nutr 60:1017S$1022 \mathrm{~S}$

Kelly MJ, Tume RK, Newman S, Thompson JM (2013) Genetic variation in fatty acid composition of subcutaneous fat in cattle. Anim Prod Sci 53:129-133

Kramer JKG, Fellner V, Dugan MER, Sauer FD, Mossoba MM, Yurawecz MP (1997) Evaluating acid and base catalysts in the methylation of milk and rumen fatty acids with special emphasis on conjugated dienes and total trans fatty acids. Lipids 32:1219-1228

Malau-Aduli AEO, Siebert BD, Bottema CDL, Pitchford WS (1997) A comparison of the fatty acid composition of triacylglycerols in adipose tissue from Limousin and Jersey cattle. Aust J Agric Res 48: $715-722$

Malau-Aduli AEO, Siebert BD, Bottema CDK, Pitchford WS (1998) Breed comparison of the fatty acid composition of muscle phospholipids in Jersey and Limousin cattle. J Anim Sci 76:766-773

Mensink RP, Katan MB (1992) Effect of dietary fatty acids on serum lipids and lipoproteins. A meta-analysis of 27 trials. Arterioscler Thromb 12:911-919

Metz PAM, Menezes LFG, Santos AP, Brondani IL, Restle J, Lanna DPD (2009) Perfil de ácidos graxos na carne de novilhos de diferentes idades e grupos genéticos terminados em confinamento. Rev Bras Zootec 38(3):523-531

Meyer K, Houle D (2013) Sampling based approximation of confidence intervals for functions of genetic covariance matrices. Proc Assoc Adv Anim Breed Genet 20:523-526

Mills EW, Comerford JW, Hollender R, Harpster HW, House B, Henning WR (1992) Meat composition and palatability of Holstein and beef steers as influenced by forage type and protein source. J Anim Sci 70:2446-2451

Misztal I, Tsuruta S, Strabel T, Auvray B, Druet T, Lee DH (2002) BLUPF90 and related programs (BGF90). In: Proceedings of the 7th World Congress on Genetics Applied to Livestock Production; August 19-23, 2002, Montpellier, France. Communication No 2807

Newman RE, Bryden WL, Fleck E, Ashes JR, Storlien LH, Downing JA (2002) Dietary n-3 and n-6 fatty acids alter avian metabolism: molecular-species composition of breast-muscle phospholipids. $\mathrm{Br}$ J Nutr 88:19-28

Nogi T, Honda T, Mukai F, Okagaki T, Oyama K (2011) Heritabilities and genetic correlations of fatty acid compositions in longissimus muscle lipid with carcass traits in Japanese Black cattle. J Anim Sci 89: 615-621

Pensel N (1998) The future of red meat in human diets. Nutr Abstr Rev (Series A) 68:1-4

Pereira ASC, Baldi F, Sainz RD, Utembergue BL, Chiaia HLJ, Magnabosco CU et al (2014) Growth performance, and carcass and meat quality traits in progeny of Poll Nellore, Angus and 
Brahman sires under tropical conditions. Anim Prod Sci 55(10): 1295-1302. doi:10.1071/AN13505

Perry D, Nicholls PJ, Thompson JM (1998) The effect of sire breed on the melting point and fatty acid composition of subcutaneous fat in steers. J Anim Sci 76:87-95

Pinto LFB, Ferraz JBS, Meirelles FV, Eler JP, Rezende FM, Carvalho ME et al (2010) Association of SNPs on CAPN1 and CAST genes with tenderness in Nellore cattle. Genet Mol Res 9(3):1431-1442

Pitchford WS, Deland MPB, Siebert BD, Malau-Aduli AEO, Bottema CDK (2002) Genetic variation in fatness and fatty acid composition of crossbred cattle. J Anim Sci 80:2825-2832

Prado IN, Moreira FB, Matsushita M, Souza NE (2003) Longissimus dorsi fatty acids composition of Bos indicus and Bos indicus $\times$ Bos taurus crossbred steers finished in pasture. Braz Arch Biol Technol 46:601-608

Riley DG, Chase CC Jr, Hammond AC, West RL, Johnson DD, Olson TA et al (2002) Estimated genetic parameters for carcass traits of Brahman cattle. J Anim Sci 80:955-962

Rossato LV, Bressan MC, Rodrigues EC, Gama LT, Bessa RJB, Alves SPA (2010) Parâmetros físico-químicos e perfil de ácidos graxos da carne de bovinos Angus e Nelore terminados em pastagem. Rev Bras Zootec 39(5):1127-1134

Rubiano GAG, Arrigoni MD, Martins CL, Rodrigues É, Gonçalves HC, Angerami CN (2009) Desempenho, características de carcaça e qualidade da carne de bovinos superprecoces das raças Canchim, Nelore e seus mestiços. Rev Bras Zootec 38(12):2490-2498

Rule DC, Macneil MD, Short RE (1997) Influence of sire growth potential, time on feed, and growing-finishing strategy on cholesterol and fatty acids of the ground carcass and Longissimus muscle of beef steers. J Anim Sci 75:1525-1533

Schutt KM, Arthur PF, Burrow HM (2009) Brahman and Brahman crossbred cattle grown on pasture and in feedlots in subtropical and temperate Australia. 3. Feed efficiency and feeding behaviour of feedlot-finished animals. Anim Prod Sci 49:452-460
Siebert BD, Deland MP, Pitchford WS (1996) Breed differences in the fatty acid composition of subcutaneous and intramuscular lipid of early and late maturing, grain-finished cattle. Aust J Agric Res 47: 943-952

Silva SL, Leme PR, Pereira ASC, Putrino SM (2003) Correlations among carcass characteristics taken by ultrasound and after slaughter in Nellore steers fed high concentrate diets. Rev Bras Zootec 32(5): $1236-1242$

Simopoulos AP (2008) The importance of the omega-6/omega-3 fatty acid ratio in cardiovascular disease and other chronic diseases. Exp Biol Med (Maywood) 233(6):674-688

Smith T, Domingue JD, Paschal JC, Franke DE, Bidner TD, Whipple G (2007) Genetic parameters for growth and carcass traits of Brahman steers. J Anim Sci 85:1377-1384

Tapiero H, Ba GN, Couvreur P, Tew KD (2002) Polyunsaturated fatty acids (PUFA) and eicosanoids in human health and pathologies. Biomed Pharmacother 56:215-222

Tatum JD, Smith GC, Carpenter ZL (1982) Interrelationships between marbling, subcutaneous fat thickness and cooked beef palatability. J Anim Sci 54(4):777-784

VanRaden PM, Van Tassell CP, Wiggans GR, Sonstegard TS, Schnabel $\mathrm{RD}$, Taylor JF et al (2009) Invited review: reliability of genomic predictions for North American Holstein bulls. J Dairy Sci 92:16-24

Vitezica ZG, Aguilar I, Misztal I, Legarra A (2011) Bias in genomic predictions for populations under selection. Genet Res (Camb) 93: 357-366

Wheeler TL, Shackelford SD, Koohmaraie M (1995) Standardized Warner-Bratzler shear force procedures for meat tenderness measurement. Roman L. Hruska U.S. Meat Animal Research Center (MARC). Agricultural Research Service (ARS), USDA, Clay Center, NE

Wood JD, Enser M, Fisher AV, Nute GR, Sheard PR, Richardson RI et al (2008) Fat deposition, fatty acid composition and meat quality: A review. Meat Sci 78:343-358 